\title{
KEHADIRAN DAN KERAGAMAN HERBA-LIANA \\ SEBAGAI SUMBER PAKAN SATWA LIAR \\ DI KAWASAN REKLAMASI PASCATAMBANG BATUBARA \\ PT KIDECO JAYA AGUNG, PASER, KALIMANTAN TIMUR
}

\author{
PRESENCE \& DIVERSITY OF HERBA-LIANA \\ AS FEEDING SOURCE OF WILDLIFE AT \\ THE AREA OF COAL POST MINING RECLAMATION \\ PT KIDECO JAYA AGUNG, PASER, EAST KALIMANTAN
}

\author{
Oleh: \\ Slamet Rohmadi ${ }^{1 \& 3}$, Yaya Rayadin², Paulus Matius² dan Yosep Ruslim² \\ ${ }^{1}$ Program Magister Ilmu Kehutanan, Universitas Mulawarman, Samarinda \\ 2 Dosen Program Studi Magister Ilmu Kehutanan, Universitas Mulawarman, Samarinda \\ ${ }^{3}$ Pengendali Ekosistem Hutan, Balai Taman Nasional Kutai \\ yrayadin@yahoo.com
}

Diterima 09-11-2018, direvisi 08-12-2018, disetujui 09-12-2018

\begin{abstract}
ABSTRAK
Kegiatan pemulihan fungsi kawasan ekosistem pasca tambang dilakukan melalui kegiatan reklamasi dan revegetasi lahan. Penilaian keberhasilan kegiatan reklamasi dan revegetasi selama ini hanya didasarkan pada pertumbuhan dan keberadaan tanaman pokoknya. Kehadiran dan keragaman jenis tumbuhan bawah herba dan liana dikawasan reklamasi pasca tambang belum menjadi indikator dalam penilaian keberhasilan kegiatan reklamasi. Kehadiran jenis herba-liana sendiri sangat penting bagi sumber pakan satwa liar yang ada didalamnya. Oleh karena ini dalam penelitian ini dilakukan perhitungan kehadiran dan keragaman jenis herba-liana pada berbagai variasi umur tanaman reklamasi yang berbeda. Tingkat keanekaragaman dan kehadiran didasarkan pada nilai frekuensi kehadiran pada masing masing subplotnya. Hasil menunjukkan bahwavariasi umur tanaman yang berbeda menunjukkan semakin berkembang umur tanaman reklamasi yang akan diikuti oleh penambahan keanekaragaman jenis herba dan liana. Frekuensi dari 176 kehadiran menunjukkan bahwa jenis yang paling banyak hadir adalah jenis Zoysia matrella 80,7\% (142 dari 176) diikuti oleh jenis Mucuna sp. $75 \%$ (132 dari 176) dan Asystasia intrusa 59,1\% (104 dari 176). Secara umum kehadiran jenis tumbuhan bawah kategori herba liana sangat penting dalam mempercepat pemulihan ekosistem pascatambang.
\end{abstract}

Kata Kunci: indeks keragaman, herba-liana, batubara, pascatambang, reklamasi.

\section{ABSTRACT}

Recovery activity of post mining ecosystem area is conducted through reclamation and land re-vegetation. Success valuation of the reclamation and re-vegetation activity so far is merely based on the growth and existence of any vegetation planted by the company. Existence and diversity of understory growth particularly species of herba and liana at the area of post-mining reclamation has not yet been indicator in valuation the success of reclamation activity. The existence of herbaliana itself is quite vital which is functioned for food source of wild animal within the area. Thus, the present study conducted calculation of existence and diversity of herb-liana species in various ages of different reclamation vegetation. The diversity index and existence of herba and liana species is based on frequency value of existence in their respective subplot. From table 11, plant age variation showed that the higher the age of a reclamation vegetation age, the higher the diversity of herba and liana species. Out of total 176 subplots/frequencies of existence, it shows that the most existing species was Zoysia matrella with percentage of 80.7\% (142 of 176) followed by Mucuna sp. species With 75\% (132 of 176) and Asystasia intrusa with percentage of $59.1 \%$ (104 of 176) in general out of various reclamation ages, herba and liana species reclamation vegetation ages can be found in varied diversities. In general, the existence of the plant classified as herba liana category plays a quite vital role in accelerating the post-mining ecosystem recovery. 
Keywords: diversity index, herb-liana, coal, postmining, reclamation.

\section{PENDAHULUAN}

Kegiatan pertambangan Batubara adalah kegiatan pengelolaan sumberdaya alam yang secara umum dilakukan dengan cara merubah kondisi tutupan lahan baik pada sekala landskap maupun pada sekala bentang alam melalui kegiatan pembukaan lahan dan pemindahan lapisan tanah (Abubakar, 2009; Delvian, 2004, Muhdi et al., 2012). Kegiatan ini menyebabkan terbukanya kondisi tanah yang dari ekosistem hutan alam menjadi lahan terbuka sehingga menyebabkan berbagai kemungkinan bencana diantaranya adalah tingginya laju erosi dan sedimentasi serta adanya perubahan kondisi iklim mikronya.Untuk mengurangi resiko kerusakan tersebut, maka dilakukan upaya pemulihan kawasan. Salah satu upaya pemulihan kondisi tutupan lahan tersebut adalah melalui kegiatan reklamasi dan revegetasi pasca tambang atau yang sering kita kenal dengan kegiatan reklamasi pasca tambang. Kegiatan reklamasi pasca tambang sendiri dilakukan secara bertahap pada setiap tahunnya dengan luasan areal reklamasi yang berbeda-beda yang disesuaikan dengan tahapan kegiatan produksinya.

Untuk mengukur indikator keberhasilan reklamasi dan pascatambang, maka pemerintah maupun perusahaan pertambangan batubara menggunakan standar penilaian, salah satunya dengan cara mengukur persentase keberhasilan jumlah tanaman pokok yang tumbuh yang didasarkan pada Permen ESDM Nomor 7 Tahun 2014. Tanaman pokok adalah tanaman yang ditanam oleh perusahaan. Jenis tanaman pokok yang ditanam biasanya merupakan jenis tanaman tahunan dari kelompok fastgrowing species dan atau pohon pioneer yang pada umumnya dapat tumbuh diareal terbuka (Setyowati et al., 2017). Selain adanya tanaman pokok, pada berbagai umur tanaman Kawasan Reklamasi Pascatambang (KRPT) juga hadir berbagai keragaman jenis flora alami yang termasuk dalam kategori pohon maupun tumbuhan bawah (herba, liana, palm, paku-pakuan) yang tumbuh secara alami pada KRPT.

Dalam tahap awal pemulihan KRPT kelompok tumbuhan bawah khususnya dari kelompok Herba-Liana dapat memberi peran sangat penting dalam mempercepat pengembalian fungsi ekosistem pascatambang. Kehadiran tumbuhan bawah dapat berperan sebagai sumber pakan awal bagi beberapa jenis satwa liar khususnya kelompok serangga dan avifauna khususnya dari kelompok herbivora (Sita \& Aunurohim 2013, Sabarno 2002). Tumbuhan bawah juga dapat berperan dalam perlindungan permukaan tanah dari tingginya laju erosi dan temperatur tanah (Soerianegara dan Indrawan, 1998). Disisi lain penelitian mengenai kehadiran dan keragaman tumbuhan bawah dari kelompok Herba-liana pada KRPT belum banyak dikaji. Kehadiran dan keragaman jenis tumbuhan bawah juga sangat penting sebagai sumber pakan utama atau sumber pakan awal bagi berbagai jenis serangga baik kelompok kumbang, kupu-kupu, capung dan kelompok 
serangga lainnya (Sita \& Aunurohim 2013). Oleh karena itu kehadiran dan keragaman jenis tumbuhan bawah kelompok herba-liana dikawasan reklamasi pascatambang sangat penting untuk dikaji dalam rangka mempercepat proses pemulihan ekosistem pascatambang melalui percepatan kehadiran satwa liar yang ada didalamnya yang merupakan tahap awal untuk perkembangan habitat selanjutnya dan mempercepat dan menahan pemulihan unsur hara (Balai Besar KSDA Jawa Timur, 2018). Untuk mengkaji lebih mendalam atas keberadaan tumbuhan bawah dari kelompok herba-liana pada KRPT, maka dilakukan penelitian keragaman dan kehadiran jenis herba-liana pada umur KRPT yang berbeda-beda di kawasan reklamasi dan revegetasi pascatambang PT Kideco Jaya Agung.

\section{METODOLOGI PENELITIAN}

\section{A. Lokasi penelitian}

Kegiatan penelitian dilakukan pada Kawasan Reklamasi Pascatambang (KRPT) PT Kideco Jaya Agung, Paser, Kalimantan Timur, pada variasi umur tanaman reklamasi yang berbeda-beda yaitu dari umur tanaman reklamasi usia 1 tahun sampai dengan 11 tahun (Tabel 1).

\section{B. Prosedur kerja}

Untuk mengetahui tingkat kehadiran dan keragaman jenis tumbuhan bawah dari kelompok herba-liana pada KRPT maka dilakukan beberapa tahapan penelitian dengan cara sebagai berikut:

1. Kegiatan identifikasi kehadiran dan keragaman jenis herba-liana dilakukan pada masing masing sub plot yang ditempatkan di dalam plot petak ukur permanen (PUP) yang sudah dibangun pada berbagai variasi umur tanaman reklamasi yang berbeda.

2. Sub plot pengamatan berukuran $2 \mathrm{~m} \times 2$ $\mathrm{m}$ diletakan pada plot PUP berukuran 20m x 20m (lihat Gambar 1). Plot PUP biasanya digunakan untuk pengamatan pertumbuhan tanaman pokok. Integrasi plot PUP dengan sub plot pengamatan herba-liana akan memudahkan dalam menganalisis dinamikan dan pertumbuhan vegetasi pascatambang pada periode-periode berikutnya.

3. Pada masing masing plot PUP ukuran $20 \mathrm{~m} \times 20 \mathrm{~m}$ dibuat 8 sub plot ukuran $2 \mathrm{~m} \times 2 \mathrm{~m}$ yang untuk selanjutnya pada masing-masing subplot tersebut disebut frekuensi kehadiran (fk). Satu sub plot mewakili satu frekuensi kehadiran untuk selanjutnya pada masing masing fk akan dilakukan identifikasi jenis-jenis yang hadir. Satu subplot akan mewakili satu frekuensi kehadiran. Tingkat kehdiran suatu jenis akan ditunjukan dengan jumlah frekuensi kehadiran dan frekuensi relatif. 


\section{Pengumpulan data}

Pengambilan data frekuensi kehadiran dilakukan pada masing-masing sub plot sebagaiman terlihat pada Gambar 1.

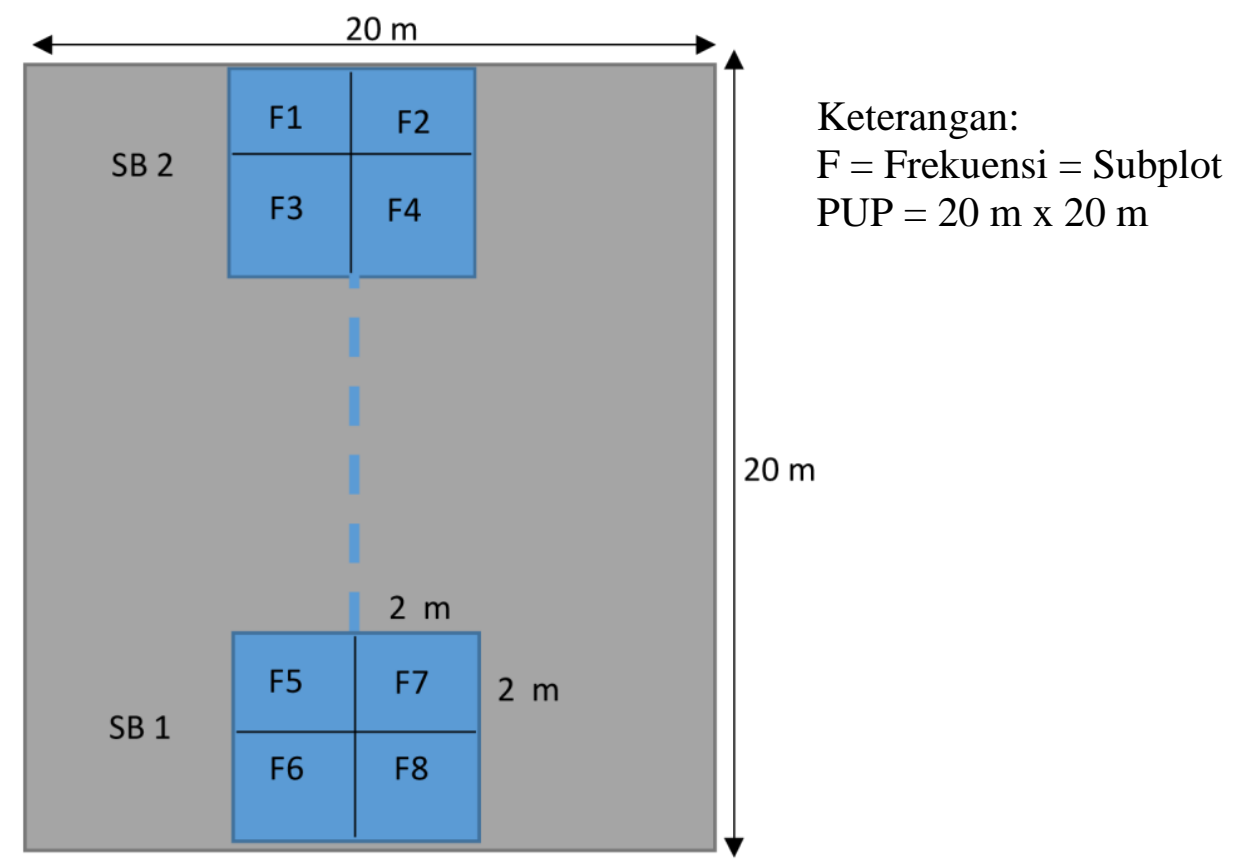

Gambar 1. Bentuk dan sebaran subplot pengamatan (F1 sd F8) yang diletakan pada masing masing plot petak ukur permanen (PUP). Setiap subplot akan mewakili frekuensi kehadirannya Figure 1. Form and distribution of observation subplots (F1 to F8) which are placed in each permanent plot plot (PUP). Each subplot will represent the frequency of its presence.

Pada masing masing umur tanaman reklamasi yang berbeda dibuat 2 plot PUP ukuran $20 \mathrm{~m}$ x 20m, untuk selanjutnya pada masing masing plot PUP dibuat 8 subplot untuk menghitung frekuensi kehadiran tumbuhan bawah herba-liana. Masing-masing sub plot berfungsi sebagai frekuensi kehadiran. Berdasarkan Tabel 1, Total frekuensi kehadiran yang dilakukan untuk pengambilan data sebanyak 176 frekuensi yang tersebar pada berbagai variasi umur tanaman yang berbeda. Bentuk PUP serta sebaran Subplot pada masing masing PUP dapat dilihat pada Gambar 1.

Jumlah plot dan subplot penelitian herbaliana di kawasan reklamasi pascatambang terdiri dari 176 petak/frekuensi dengan rincian sebagaimana terlihat pada Tabel 1 . 
Tabel 1. Jumlah plot dan subplot penelitian pada berbagai variasi umur tanaman reklamasi yang berbeda.

Table 1 . The number of plots and subplots of the study on various variations in the age of different reclamation plants.

\begin{tabular}{cccc}
\hline $\begin{array}{l}\text { Umur tanaman } \\
\text { (tahun) }\end{array}$ & $\begin{array}{l}\text { PUP/Plot } \\
20 \mathrm{~m} \mathrm{X} \mathrm{20} \mathrm{m}\end{array}$ & $\begin{array}{l}\text { Subplot/Frekuensi } \\
2 \mathrm{~m} \mathrm{x} \mathrm{2} \mathrm{m}\end{array}$ & $\begin{array}{l}\text { Total Frekuensi } \\
2 \mathrm{~m} \mathrm{x} \mathrm{2} \mathrm{m}\end{array}$ \\
\hline 1 & 2 & 8 & 16 \\
\hline 2 & 2 & 8 & 16 \\
\hline 3 & 2 & 8 & 16 \\
\hline 4 & 2 & 8 & 16 \\
\hline 5 & 2 & 8 & 16 \\
\hline 6 & 2 & 8 & 16 \\
\hline 7 & 2 & 8 & 16 \\
\hline 8 & 2 & 8 & 16 \\
\hline 9 & 2 & 8 & 16 \\
\hline 10 & 2 & 8 & 176 \\
\hline 11 & 2 & 8 &
\end{tabular}

Keterangan : Pada masing masing umur tanam di buat 2 Plot/PUP (Petak Ukur Permanen), pada masing masing Plot/PUP di buat 8 sub plot. $F_{\text {tot }}=$ Jumlah Subplot atau frekuensi secara keseluruhan $($ Umur Tanam x 2 Plot x 8 Subplot $=176$ )

\section{Analisa data}

Setiap sub plot pengamatan untuk selanjutnya disebut frekuensi $(f)$. Sehingga kehadiran jenis tumbuhan bawah kelompok herba-liana dapat dihitungan dengan menggunakan pendekatan frekuensi relatif kehadiran masing masing jenis tumbuhan bawah herba-liana sebagaimana model perhitungan berikut:

$$
F R=\frac{\sum F i}{\sum F t o t}
$$

$F R=$ Frekuensi relatif kehadiran jenis i

$\sum F i=$ Jumlah frekuensi kehadiran Jenis i

$\sum F$ tot $=$ Jumlah total frekuensi (dalam penelitian ini ada 176)

Untuk mengetahui perbandingan kehadiran jenis pada dua umur tanaman reklamasi yang berbeda maka digunakan Index Similarity
Sorenses (ISS) (Soerianegara dan Indrawan, 1998) dengan formula sebagai berikut:

$$
I S S=\frac{2 M}{m 1+\mathrm{m}^{2}} \times 100 \%
$$

$\mathrm{m}=$ jumlah species yang hadir pada 2 lokasi umur tanaman yang berbeda $\mathrm{m} 1=$ Jumlah species di lokasi 1saja $\mathrm{m} 2=$ jumlah species di lokasi 2 saja

Untuk menghitung peningkatan jenis yang berhasil diidentifikasi pada masing masing umur tanaman digunakan dengan menggunakan grafik penambahan jenis.

\section{HASIL DAN PEMBAHASAN}

Untuk mengetahui kehadiran dan keragaman jenis tumbuhan bawah pada umur KRPT yang berbeda maka dilakukan identifikasi kehadiran jenis tumbuhan bawah herba-liana 
pada masing-masing sub plot yang untuk selanjutnya masing-masing sub plot tersebut menjadi frekuensi kehadiran. Jumlah frekuensi kehadiran jenis tumbuhan bawah dibagi dengan total frekuensi (176) disebut frekuensi relatif.
Menghitung intensitas kehadiran dengan menggunakan nilai frekuensi relatif akan lebih mudah untuk mendeteksi tingkat sebaran tumbuhan bawah pada masing-masing umur KRPT yang berbeda. Adapun keragaman jenis yang hadir pada masing-masing umur KRPT yang berbeda dapat di lihat pada Tabel 2 .

Tabel 2. Frekuensi kehadiran jenis tumbuhan bawah pada berbagi variasi umur tanaman KRPT yang berbeda.

Table 2. The frequency of presence of understorey species in various variations in the age of different KRPT plants.

\begin{tabular}{|c|c|c|c|c|c|c|c|c|c|c|c|c|c|c|c|}
\hline \multirow{2}{*}{ NO } & \multirow{2}{*}{ Nama Jenis } & \multirow{2}{*}{ Family } & \multicolumn{11}{|c|}{ Umur Tanaman } & \multirow{2}{*}{ Ftot } & \multirow{2}{*}{$\begin{array}{l}\mathrm{Fr} \\
(\%)\end{array}$} \\
\hline & & & 1 & 2 & 3 & 4 & 5 & 6 & 7 & 8 & 9 & 10 & 11 & & \\
\hline 1 & Zoysia matrella & Poaceae & 16 & 12 & 12 & 8 & 16 & 16 & 12 & 12 & 8 & 14 & 16 & 142 & 80.68 \\
\hline 2 & Mucuna sp. & Leguminosae & 8 & 14 & 15 & 7 & 16 & 15 & 11 & 12 & 14 & 12 & 8 & 132 & 75.00 \\
\hline 3 & Asystasia intrusa & Acanthaceae & 8 & 16 & 16 & & 16 & 16 & 16 & & & & 16 & 104 & 59.09 \\
\hline 4 & $\begin{array}{l}\text { Scleria purpurascens } \\
\text { Benth. }\end{array}$ & Cyperaceae & 8 & & & 9 & & 8 & 16 & 16 & 11 & 15 & 16 & 99 & 56.25 \\
\hline 5 & $\begin{array}{l}\text { Melastoma } \\
\text { malabatricum }\end{array}$ & Melastomataceae & 16 & & & 9 & 8 & 11 & 1 & 13 & & 3 & 16 & 77 & 43.75 \\
\hline 6 & Eupatorium odoratum & Compositae & 8 & 4 & & 10 & 4 & 9 & 12 & 6 & 4 & 12 & 7 & 76 & 43.18 \\
\hline 7 & Imperata cylindrica & Gramineae & 14 & 16 & 7 & 4 & & 8 & & 8 & & 4 & 4 & 65 & 36.93 \\
\hline 8 & Mikania micranta & Asteraceae & 16 & 15 & 4 & 3 & & 3 & 3 & & & 3 & & 47 & 26.70 \\
\hline 9 & Mimosa pudica $L$. & Leguminosae & & 7 & & 6 & 8 & & 5 & 4 & 4 & 8 & & 42 & 23.86 \\
\hline 10 & Clidemia hirta & Melastomataceae & & & & 12 & & & 3 & 6 & 2 & 9 & 4 & 36 & 20.45 \\
\hline 11 & Calliandra sp. & Mimosaceae & & & 6 & & & & & 1 & 6 & 11 & & 24 & 13.64 \\
\hline 12 & Merremia peltata & Convolvulaceae & 2 & & & 1 & 1 & 7 & 2 & 3 & 1 & 7 & & 24 & 13.64 \\
\hline 13 & $\begin{array}{ll}\text { Solanum } & \text { torvum } \\
\text { Schltdl. } & \\
\end{array}$ & Solanaceae & 4 & 4 & & & & 3 & 4 & & 2 & 1 & & 18 & 10.23 \\
\hline 14 & Lygodium circinatum & Schizaeaceae & & & & & 2 & 2 & 3 & 3 & & 2 & & 12 & 6.82 \\
\hline 15 & Urophyllum sp. & Rubiaceae & & & & & & 1 & & & & & 10 & 11 & 6.25 \\
\hline 16 & Leea indica & Leeaceae & & & 2 & & & 1 & & 2 & 4 & 1 & & 10 & 5.68 \\
\hline 17 & Lantana camara & Verbenaceae & & & & 3 & & & 3 & & & & 2 & 8 & 4.55 \\
\hline 18 & Scirpus sp. & Cyperaceae & 8 & & & & & & & & & & & 8 & 4.55 \\
\hline 19 & Bauhinia lingua & Leguminosae & & & & & & & & & & & 7 & 7 & 3.98 \\
\hline 20 & Dicranopteris linearis & Gleicheniaceae & & & & 3 & & 4 & & & & & & 7 & 3.98 \\
\hline 21 & Passiflora foetida & Passifloraceae & & & & & & & 1 & 3 & & 3 & & 7 & 3.98 \\
\hline 22 & Hyptis capitata & Labiatae & & & 3 & & & 2 & & & & 1 & & 6 & 3.41 \\
\hline 23 & $\begin{array}{l}\text { Tetracera scandens } \\
\text { Merr. }\end{array}$ & Dilleniaceae & & & & & & & & & 5 & & & 5 & 2.84 \\
\hline 24 & $\begin{array}{l}\text { Blechnum } \\
\text { orientale Linn. }\end{array}$ & Blechnaceae & & & & & & 4 & & & & & & 4 & 2.27 \\
\hline 25 & Cyperus sp. & Cyperaceae & 4 & & & & & & & & & & & 4 & 2.27 \\
\hline 26 & Gleichenia linearis & Gleicheniaceae & & & & & & & & & & & 4 & 4 & 2.27 \\
\hline 27 & Histiopteris incisa & Dennstaedtiaceae & & & & & & & & & & & 4 & 4 & 2.27 \\
\hline 28 & Nephrolepis falcata & Oleandraceae & & & & & & 4 & & & & & & 4 & 2.27 \\
\hline
\end{tabular}




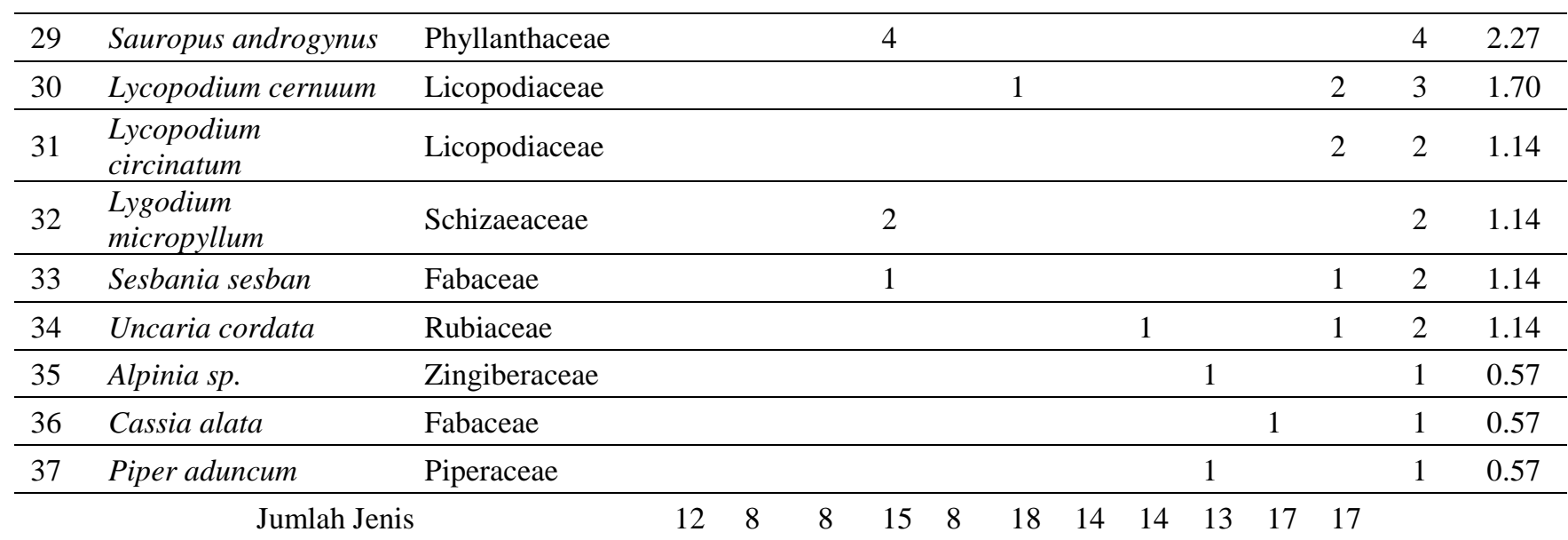

Berdasarkan Tabel 2 terlihat bahwa jumlah jenis tumbuhan bawah kelompok herba-liana yang berhasil diidentifikasi berjumlah 37 jenis yang termasuk kedalam 27 famili. Beberapa jenis tumbuhan bawah menunjukan fenomena yang menarik dimana jenis Scirpus $s p$ dan Cyperus $s p$ hanya hadir pada KRPT yang berumur 1 tahun yaitu kawasan KRPT dengan kondisi tutupan tajuk yang relatif terbuka.

Berdasarkan Tabel 2, menunjukkan bahwa nilai frekuensi relatif kehadiran jenis yang paling tinggi yaitu jenis Zoysia matrella $(80,7 \%)$ diikuti oleh jenis Mucuna sp. (75\%) dan Asystasia intrusa (59\%). Jenis Zoysia matrella dan Mucuna sp. menghasilkan nilai frekuensi relatif yang paling tinggi. Hal ini dikarenakan kedua jenis tersebut hadir pada berbagai variasi umur tanaman KRPT. Dari tabel 2 juga terlihat bahwa nilai frekuensi relatif yang paling rendah adalah jenis Alpinia sp. (0,57\%) diikuti oleh jenis Cassia alata (0,57\%), Piper aduncum (0,57\%). Jenisjenis tersebut hanya hadir dan ditemukan hanya pada 1 petak pengamatan pada kawasan KRPT yang relatif tua yaitu KRPT umur 9 s/d 10 tahun.

Berdasarkan Gambar 2 menunjukkan bahwa adanya penambahan umur KRPT menunjukkan penambahan jumlah jenis yang bervariasi. Hal ini dikarenakan secara umum kondisi tanah pada seluruh kawasan KRPT relatif sama yaitu tanaman dengan kedalaman top soil hasil kegiatan reklamasi lahan sedalam $20 \mathrm{~s} / \mathrm{d} 50 \mathrm{~cm}$. Sehingga faktor kedalaman tanah diperkirakan juga berpengaruh kehadiran dan keanekaragaman jenis tumbuhan bawah yang hadir (Kunarso dan Azwar, 2012). 


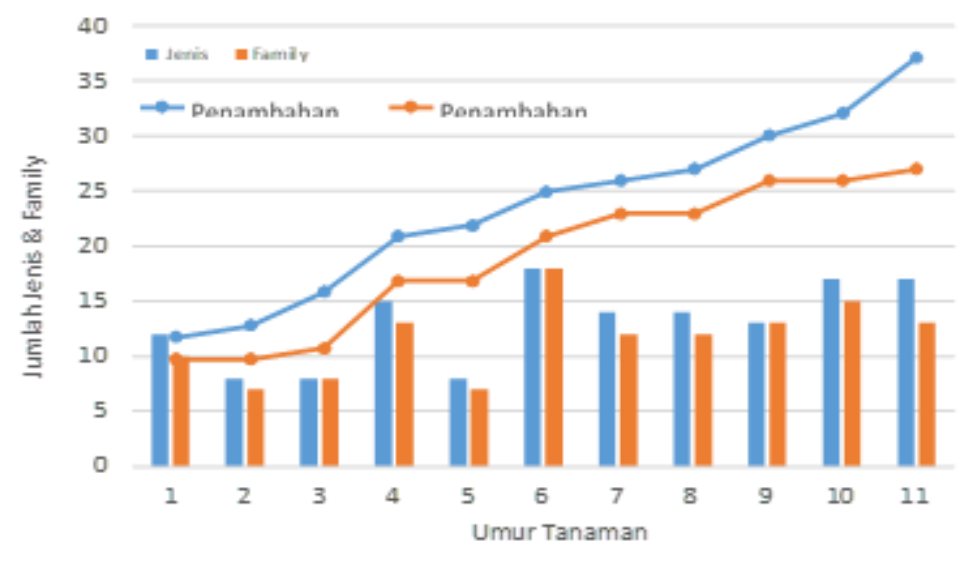

Gambar 2. Grafik jumlah jenis dan family pada berbagai variasi umur KRPT yang berbeda (Box) serta pertambahan jenis dan family yang berhasil di inventarisasi dan di identifikasi sering dengan peningkatan umur tanaman reklamasi (line)

Figure 2. Graph of the number of species and family in various variations of the age of different KRPT (Box) as well as the increase in species and families that were successfully inventoryed and identified often with an increase in the age of reclamation (line)

Beberapa hasil penelitian terkait dengan rumpang juga menyatakan bahwa rumpang atau keterbukaan tajuk pohon akan berpengaruh pada tumbuhan bawahnya (Wang, 2010). Secara umum kehadiran jenis tumbuhan bawah di berbagai kawasan reklamasi, kemungkinan lebih banyak dipengaruhi oleh kondisi tanah dan kondisi tutupan tajuk (Istomo et al., 2013). Adanya peningkatan umur tanaman menyebabkan kondisi tutupan tajuk semakin tertutup sehingga hadir beberapa jenis-jenis tumbuhan bawah baru yang lebih tahan di tempat yang relatif tertutup (Setiawan et al., 2017).

Jumlah kehadiran jenis pada masing masing umur tanaman KRPT dapat dilihat pada
Gambar 1 dimana jumlah jenis tumbuhan bawah tertinggi terdapat pada tanaman reklamasi berumur 6 tahun sebanyak 18 jenis diikuti oleh KRPT umur 10 tahun 17 jenis, dan KRPT umur 11 tahun 17 jenis.

Pada Gambar 2 juga menunjukkan bahwa seiring dengan bertambahnya umur tanaman reklamasi akan diikuti pula oleh peningkatan keanekaragaman jumlah jenis tumbuhan bawah herba-liana yang berhasil diidentifikasi. Untuk mengetahui persentase kesamaan jenis herbaliana dikawasan reklamasi maka dilakukan perhitungan index kesamaan jenis Sorensen sebagaimana terdapat pada Tabel 3. 
Tabel 3. Indeks keragaman jenis pada masing-masing umur tanaman KRPT yang berbeda

Table 3. Diversity index for each age of different KRPT plants

\begin{tabular}{|c|c|c|c|c|c|c|c|c|c|c|c|}
\hline \multirow{2}{*}{ ISS } & \multicolumn{11}{|c|}{ Umur KRPT (Tahun) } \\
\hline & 1 & 2 & 3 & 4 & 5 & 6 & 7 & 8 & 9 & 10 & 11 \\
\hline 1 & & & & & & & & & & & \\
\hline 2 & 70.0 & & & & & & & & & & \\
\hline 3 & 50.0 & 62.5 & & & & & & & & & \\
\hline 4 & 59.3 & 52.2 & 34.8 & & & & & & & & \\
\hline 5 & 60.0 & 62.5 & 37.5 & 52.2 & & & & & & & \\
\hline 6 & 66.7 & 53.9 & 53.9 & 54.6 & 53.9 & & & & & & \\
\hline 7 & 69.2 & 63.6 & 36.4 & 69.0 & 72.7 & 62.5 & & & & & \\
\hline 8 & 53.9 & 45.5 & 45.5 & 62.1 & 63.6 & 56.3 & 71.4 & & & & \\
\hline 9 & 48.0 & 38.1 & 38.1 & 50.0 & 47.6 & 45.2 & 59.3 & 66.7 & & & \\
\hline 10 & 62.1 & 56.0 & 56.0 & 62.5 & 56.0 & 68.6 & 77.4 & 83.9 & 66.7 & & \\
\hline 11 & 56.0 & 40.0 & 32.0 & 56.3 & 40.0 & 51.4 & 51.6 & 51.6 & 33.3 & 41.2 & \\
\hline
\end{tabular}

Index kesamaan jenis tertinggi sebesar 83,9 pada KRPT umur 8 tahun dan 9 tahun hal ini cukup beralasan mengingat variasi umur dan kondisi KRPT yang tidak jauh berbeda. Sementara itu kesamaan jenis terendah sebesar $32 \%$ pada KRPT umur 3 dan 10 tahun. Hal ini dikarenakan variasi umur tanaman yang begitu jauh. Secara umum perbedaan umur tanaman mempengaruhi terhadap nilai persentase kesamaan jenisnya. Hal yang menarik adalah bahwa setiap adanya pertambahan umur tanaman KRPT akan diikuti juga oleh penambahan jenis baru dari kelompok herba-liana.

Pada Tabel 4, menunjukkan bahwa dari ke 37 jenis tumbuhan bawah sebanyak 29 jenis merupakan pohon pakan bagi beberapa kelompok serangga (kupu-kupu dan capung) serta beberapa jenis burung. Oleh karena itu kehadiran jenis tumbuhan bawah di kawasan reklamasi selain bermanfaat untuk konservasi tanaman dalam menekan laju erosi dan sedimentasi juga berfungsi sebagai sumber pohon pakan bagi beberapa jenis satwa kelompok herbivore (Sadili, 2010; Riswan et al., 2015). Kehadiran beberapa jenis satwa yang memanfaatkan tumbuhan bawah di kawasan reklamasi pasca tambang sebagai sumber pakannya merupakan langkah awal untuk membangun fungsi ekosistem melalui interaksi antara satwa liar dan tumbuhan yang ada didalam kawasan KRPT. Interaksi antara tumbuhan dan satwa liar yang ada didalamnya akan mempercepat pemulihan fungsi ekosistem pascatambang (Marshall, 2015; Ridha dan Prasetyo, 2018). 
Tabel 4. Kehadiran Jenis Tumbuhan Bawah di KRPT sebagai sumber pakan satwa

Table 4. Presence of Lower Plants in KRPT as a source of animal feed

\begin{tabular}{|c|c|c|c|c|c|c|c|}
\hline \multirow[b]{2}{*}{ No } & \multirow[b]{2}{*}{ Nama Jenis } & \multirow[b]{2}{*}{ Family } & \multirow[b]{2}{*}{ Frekuensi } & \multirow{2}{*}{$\begin{array}{c}\text { Frekuensi } \\
\text { Relatif } \\
(\%)\end{array}$} & \multicolumn{3}{|c|}{ Pakan Satwa } \\
\hline & & & & & Daun & Bunga & Buah \\
\hline 1 & Zoysia matrella & Poaceae & 142 & 80.7 & $\sqrt{ }$ & & \\
\hline 2 & Mucuna sp. & Leguminosae & 132 & 75.0 & & & \\
\hline 3 & Asystasia intrusa & Acanthaceae & 104 & 59.1 & $\sqrt{ }$ & & \\
\hline 4 & Scleria purpurascens Benth. & Cyperaceae & 99 & 56.3 & $\sqrt{ }$ & & \\
\hline 5 & Melastoma malabatricum & Melastomataceae & 77 & 43.8 & $\sqrt{ }$ & $\sqrt{ }$ & $\sqrt{ }$ \\
\hline 6 & Eupatorium odoratum & Compositae & 76 & 43.2 & $\sqrt{ }$ & & \\
\hline 7 & Imperata cylindrica & Gramineae & 65 & 36.9 & $\sqrt{ }$ & & \\
\hline 8 & Mikania micranta & Asteraceae & 47 & 26.7 & $\sqrt{ }$ & & \\
\hline 9 & Mimosa pudica L. & Leguminosae & 42 & 23.9 & $\sqrt{ }$ & & \\
\hline 10 & Clidemia hirta & Melastomataceae & 36 & 20.5 & & & \\
\hline 11 & Calliandra sp. & Mimosaceae & 24 & 13.6 & $\sqrt{ }$ & $\sqrt{ }$ & \\
\hline 12 & Merremia peltata (L.) Merr. & Convolvulaceae & 24 & 13.6 & & & \\
\hline 13 & Solanum torvum Schltdl. & Solanaceae & 18 & 10.2 & $\sqrt{ }$ & $\sqrt{ }$ & $\sqrt{ }$ \\
\hline 14 & Lygodium circinatum $S w$. & Schizaeaceae & 12 & 6.8 & $\sqrt{ }$ & & \\
\hline 15 & Urophyllum sp. & Rubiaceae & 11 & 6.3 & $\sqrt{ }$ & & \\
\hline 16 & Leea indica & Leeaceae & 10 & 5.7 & $\sqrt{ }$ & $\sqrt{ }$ & $\sqrt{ }$ \\
\hline 17 & Lantana camara & Verbenaceae & 8 & 4.5 & $\sqrt{ }$ & $\sqrt{ }$ & \\
\hline 18 & Scirpus sp. & Cyperaceae & 8 & 4.5 & & & \\
\hline 19 & Bauhinia lingua & Leguminosae & 7 & 4.0 & $\sqrt{ }$ & & \\
\hline 20 & Dicranopteris linearis & Gleicheniaceae & 7 & 4.0 & $\sqrt{ }$ & & \\
\hline 21 & Passiflora foetida & Passifloraceae & 7 & 4.0 & & $\sqrt{ }$ & $\sqrt{ }$ \\
\hline 22 & Hyptis capitata & Labiatae & 6 & 3.4 & & & \\
\hline 23 & Tetracera scandens Merr. & Dilleniaceae & 5 & 2.8 & $\sqrt{ }$ & & \\
\hline 24 & Blechnum orientale Linn. & Blechnaceae & 4 & 2.3 & $\sqrt{ }$ & & \\
\hline 25 & Cyperus sp. & Cyperaceae & 4 & 2.3 & & & \\
\hline 26 & Gleichenia linearis & Gleicheniaceae & 4 & 2.3 & & & \\
\hline 27 & $\begin{array}{l}\text { Histiopteris incisa } \\
\text { (Thunb.) J.Sm. }\end{array}$ & Dennstaedtiaceae & 4 & 2.3 & & & \\
\hline 28 & $\begin{array}{l}\text { Nephrolepis falcata } \\
\text { (Cav.) C.Chr. }\end{array}$ & Oleandraceae & 4 & 2.3 & & & \\
\hline 29 & Sauropus androgynus & Phyllanthaceae & 4 & 2.3 & $\sqrt{ }$ & & \\
\hline 30 & Lycopodium cernuиm & Licopodiaceae & 3 & 1.7 & & & \\
\hline 31 & Lycopodium circinatum & Licopodiaceae & 2 & 1.1 & & & \\
\hline 32 & Lygodium microphyllum & Schizaeaceae & 2 & 1.1 & & & \\
\hline 33 & Sesbania sesban & Fabaceae & 2 & 1.1 & $\sqrt{ }$ & & \\
\hline 34 & Uncaria cordata & Rubiaceae & 2 & 1.1 & & & \\
\hline 35 & Cassia alata & Fabaceae & 1 & 0.6 & & & \\
\hline 36 & Piper aduncum & Piperaceae & 1 & 0.6 & & & $\sqrt{ }$ \\
\hline 37 & Alpinia sp. & Zingiberaceae & 1 & 0.6 & & $\sqrt{ }$ & $\sqrt{ }$ \\
\hline
\end{tabular}




\section{KESIMPULAN}

Pada berbagai umur KRPT yang berbeda menunjukkan variasi kehadiran jenis tumbuhan bawah yang beragam. Kehadiran beberapa jenis tumbuhan bawah di KRPT sangat penting bagi sumber pakan satwa. Dari 37 jenis tumbuhan bawah yang berhasil diidentifikasi, terdapat 24 jenis yang dapat berfungsi sebagai sumber pakan satwa terutama kelompok serangga dan burung jenis herbivor. Karena kehadiran jenis tumbuhan bawah di KRPT sangat penting baik sebagai pengendali erosi maupun sebagai sumber pakan maka konservasi tumbuhan bawah di KRPT yang berbeda perlu dilakukan secara efektif.

Jenis tumbuhan bawah yang berfungsi sebagai sumber pakan satwa agar dapat dipertahankan. Namun beberapa jenis, tumbuhan bawah terutama dalam kelompok liana yang menghambat pertumbuhan tanaman pohon dapat dilakukan pengendalian dan pembebasan secara rutin.

\section{DAFTAR PUSTAKA}

Abubakar, F. 2009. Evaluasi Tingkat Keberhasilan Revegetasi Lahan Bekas Tambang Nikel di PT Inco Tbk. Sorowako, Sulawesi Selatan. Jurnal Ilmiah Rimba Kalimantan. 6(2):9-14.

Balai Besar KSDA Jawa Timur. 2018. Pemulihan Ekosistem Melalui Perdirjen P. 12 Tahun 2015. http://bbksdajatim.org/pemulihan-ekosistemmelalui-perdirjen-p-12-tahun-2015.php diunduh 7 Desember 2018.

Delvian. 2004. Aplikasi Cendawan Mikoriza Arbuskula Dalam Reklamasi Lahan Kritis Pasca Tambang. Disertasi. Sekolah Pacasarjana Institut Pertanian Bogor. Bogor.
Istomo, Setiadi Y, Putri AN. 2013. Evaluasi Keberhasilan Tanaman Hasil Renegetasi Di Lahan Pasca Tambang Batubara Site Lati PT. Berau Coal Kalimantan Timur. 4(2):77-81.

Kunarso A. dan Azwar F. 2012. Keragaman Jenis Tumbuhan Bawah Pada berbagai Tegakan Hutan Tanaman Di benakat, Sumatera Selatan. Jurnal Penelitian Hutan Tanaman. 10(2):85-98.

Marshall, AJ. 2015. Interaksi antara tumbuhan dan hewan. Bahan Uliah Lapangan TN Gunung Palung. https://sites.lsa.umich.edu/wpcontent/uploads/sites/162/2015/06/Andy-2.Interaksi-antara-tumbuhan-dan-vertebrat.pdf diunduh 7 Desember 2018.

Muhdi, Elias, Murdiyarso D, Matangaran JR. 2012. Kerusakan Tegakan Tinggal Akibat Pemanenan Kayu Reduced Impact Logging dan Konvensional di Hutan Alam Tropika, Kalimantan Timur. Jurnal Manusia dan Lingkungan. 19(3):303-311.

Peraturan Menteri Energi Sumber Daya Mineral Republik Indonesia. 2014. Peraturan ESDM Nomor 07 Tahun 2014 tentang Pelaksanaan Reklamasi dan Pascatambang pada Kegiatan Usaha Pertambangan Mineral dan Batubara.

Ridha, SR dan Prasetyo, EY. 2018. Arsitektur sebagai Media Interaksi Manusia dan Hewan. Jurnal Sains dan Seni Pomits. 7 (1): 2337-3520 (2301-928X Print).

Riswan, Harun U, Irsan C. 2015. Keragaman Flora Di Lahan Reklamasi Pasca Tambang Batubara PT BA Sumatera Selatan. Jurnal Manusia dan lingkungan. 22(2):160-168.

Sadili, A. 2010. Struktur dan Komposisi Jenis Tumbuhan Herba dan Semai Pada Habitat Satwa Herbivor di Suaka Margasatwa Cikepuh, Sukabumi, Jawa Barat. Jurnal Berita Biologi. 10(1):51-57.

Sita V. dan Aunurohim. 2013. Tingkah laku makan rusa sambar (Cervus unicolor) dalam konservasi ex situ di Kebun Binatang Surabaya. Jurnal Sains dan Seni Pomits. 2 (1), 2337-3520.

Setiawan KA, Sutedjo, Matius P. 2017. Komposisi Jenis Tumbuhan Bawah Di Lahan Revegetasi Pasca Tambang Batubara. Ulin-Jurnal Hutan Tropis. 1(2):182-195.

Setyowati DN, Amala NA, Aini NNU. 2017. Studi Pemilihan Revegetasi Untuk Keberhasilan Reklamasi Lahan Bekas Tambang. AL-ARD: Jurnal Teknik Lingkungan. 3(1):14-20. 
Soeranegara I dan Indrawan. 1998. Ekologi Hutan Indonesia. Laboratorium Ekologi Hutan. Fakultas Kehutanan. Institut Pertanian Bogor. Bogor.

Subowo G. 2011. Penambangan Sistem Terbuka Ramah Lingkungan dan Upaya Reklamasi Pascatambang untuk Memperbaiki Kualitas Sumberdaya Lahan dan Hayati Tanah, Balai Penelitian tanah, Bogor.

Sabarno MY. 2002. Savana Taman Nasional Baluran. Biodiversitas. 3(1): 207-212.
Wang Hua-Feng, Lencinas M., Friedman C. R., X.Wang, J. Qiu. 2010. Understory Plant DiversityAssesment of Eucalyptus Plantations Over Three Vegetation Types in Yunnan, China.Online Journal.Springer Science + Business Media B.V.

Marshall, AJ. 2015. Interaksi antara tumbuhan dan hewan. Bahan Uliah Lapangan TN Gunung Palung. https://sites.lsa.umich.edu/wpcontent/uploads/sites/162/2015/06/Andy-2.Interaksi-antara-tumbuhan-dan-vertebrat.pdf diunduh 7 Desember 2018. 